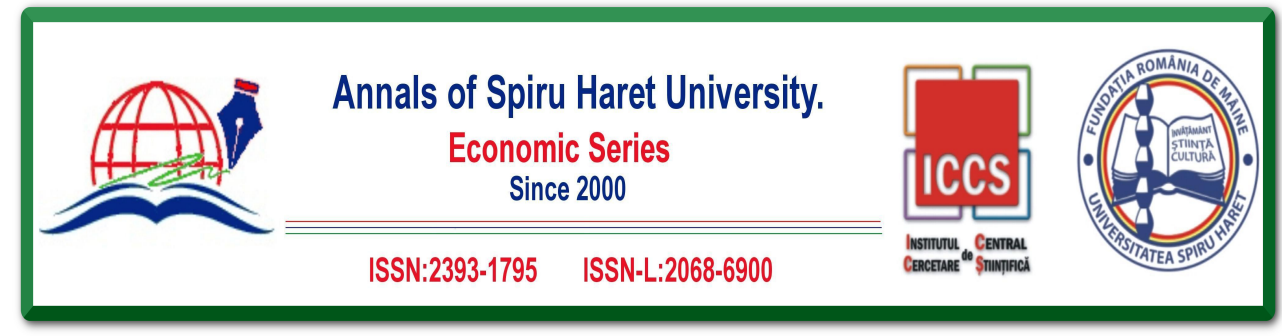

Issue 2/2019

\title{
KEY FACTORS FOR THE SUCCESSFUL IMPLEMENTATION OF THE NATIONAL INNOVATION POLICY: THE CASE OF LITHUANIA
}

\author{
Vita JUKNEVIČIENÉ ${ }^{1}$ \\ ${ }^{1}$ Šiauliai University, Institute of Regional Development, P. Visinskio str. \\ 25-402, Siauliai, LT76351, Lithuania, Phone: +37067779357 , \\ Email:v.jukneviciene@gmail.com
}

How to cite: Jukneviciene, V. (2019). "Key Factors For the Successful Implementation of the National Innovation Policy: The Case of Lithuania." Annals of Spiru Haret University. Economic Series, 19(2), 25-50, doi: https://doi.org/10.26458/1921

\begin{abstract}
Innovations play the crucial role in the economic growth in modern countries. It requires the technological progress and smart people as two main resources, needed for the actors in the national innovation system. Results of the national innovation system depend on the national innovation policy: its goals and priorities set in the agenda, policy formulation and adoption, its implementation process and its correction after the evaluation. But despite of the same stages of the public policy cycle, some countries implement the successful innovation policy (gain competitive advantage and the economicsocial benefit from it) and some countries struggle (they try to catch-up other countries in the field of innovations).

Lithuania as a small developed country in the EU has made a huge progress in terms of economics, social and technological advantage. However, despite of declared goals of innovation policy and the priorities in national strategies, governmental funding, promotion and support, the national progress in innovations in Lithuania still remains low. Therefore, stimulus and barriers for the successful implementation of Lithuanian innovation policy should be identified and analyzed, looking for problems and possible solutions.
\end{abstract}




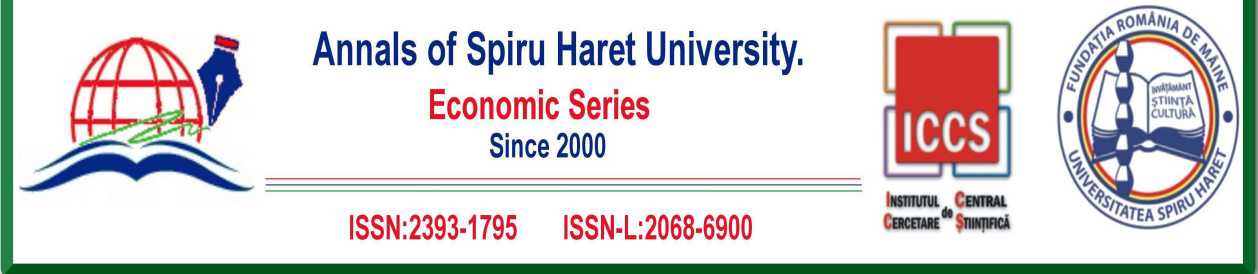

Issue 2/2019

This paper aims to explain main theoretical implications about the successful implementation of innovation policy and to reveal how it is reflected in the case of national innovation policy in Lithuania. Scientific methods of the literature analysis, document analysis, secondary data analysis, summarizing, and interpretation are used in the research.

Keywords: innovation policy; national innovation system; innovative activities.

JEL Classification: O38, O31

\section{Introduction}

Knowledge and innovations become most important sources in processes of the global and local progress. In processes of the socio-economic development or gaining competitive advantage in the market, innovative activities and their development are vitally important for organizations, sectors, countries. Those activities require the technological progress and smart people as two main resources, needed for the actors in the national innovation system.

A national innovation system (hereinafter - NIS) comprises all important economic, social, political, organizational, institutional and other factors, influencing innovations' development, diffusion and exploitation [Edquist, 2004]. It is considered as the network of public and private sectors' institutions (NIS actors), who's activities and interactions initiate, import, adopt and disseminate new decisions, technologies [Juknevičiené, 2015]. Main functions of a NIS are knowledge generation, their exploitation and dissemination, innovations' commercialization, training of $R \& D$ personnel, management of innovative processes, coordination, legal regulation, mediation, financial support, etc. The national innovation system (activity and results of its actors and the system as the whole) depends on the national public policy (especially on the innovation policy as a sphere of public policy).

Innovation policies of developed, "knowledge-based" societies are becoming increasingly inclusive object of scientific researches [Meissner et al., 2017]. "Innovation policy comprises all combined actions that are undertaken by public organizations that influence innovation processes" [Borrás \& Edquist, 2013]. It is agreed that policies to stimulate innovation at national and local levels must both 


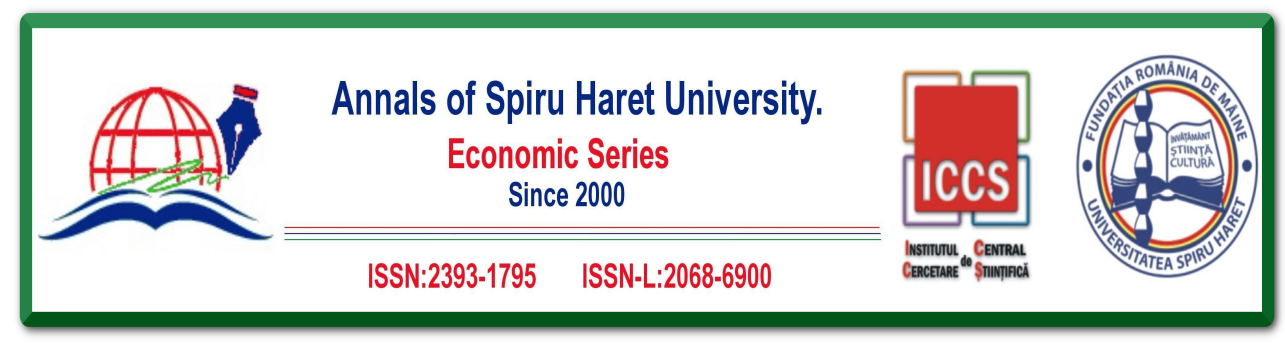

Issue 2/2019

build on and contribute to the dynamics of the national innovation system [den Hertog et al., 2001]. However, despite of the quite clear understanding of the innovation policy mission and its formulation process [including all stages of the public policy cycle and using guidelines, tools and measures of the good practice of foreign countries or international organizations (such as OECD, EU, UN)] outcomes of the innovation policy (results achieved by different NISs) differ in various countries: some countries gain the competitive advantage from innovations (i.e. innovation leaders or strong innovators such as Switzerland, Austria, Belgium, etc.), some still have to catch-up (i.e. moderate or modest innovators such as Estonia, Lithuania, Romania, etc.).

Lithuania as a small European country (the southernmost of Europe's Baltic States, the area takes 65.3 thousand $\mathrm{km}^{2}$, the population is 2.872 million people) has made a huge socio-economic progress in recent 25 years. From the post-soviet lagging behind country in 1990s (with the 7.76 billion Euros GDP in 1995) it became a country (with the 41.9 billion Euros GDP in 2017) added to the group of the advanced economies by International Monetary Fund (IMF) in 2015 [International Monetary Fund, 2015; Lithuania GDP, 2018]. The socio-economical development was (is) always one of crucial priorities of Lithuanian national strategy, the goal of public policy, the aim of governmental institutions and its society. Innovation, its development and promotion are declared as the essential direction of the Lithuanian economy, a guarantee for competitiveness and welfare growth of the country [Innovation Policy, 2018]. But despite of all efforts results of Lithuanian NIS still remains low, i.e. Lithuania is considered a moderate innovator (ranks $24^{\text {th }}$ in 2016 and $16^{\text {th }}$ in 2017 in the EU Innovation Scoreboard) [European Commission, 2017; Paliokaite et al., 2018].

The aim of this research is to explain main theoretical implications about the successful implementation of innovation policy and to reveal how it is reflected in the case of national innovation policy in Lithuania. Here the scientific problem can be defined by four problematic questions: What are the characteristics of the national innovation policy as a sphere of a public policy? What are main theoretical factors of the successful implementation of the national innovation policy? How they are reflected in the Lithuanian innovation policy? What are the stimulus and barriers for the successful implementation of Lithuanian innovation policy? Those questions directly reflect research tasks. Scientific methods of the literature analysis, document analysis, secondary data analysis, summarizing, and interpretation are used in the research. 


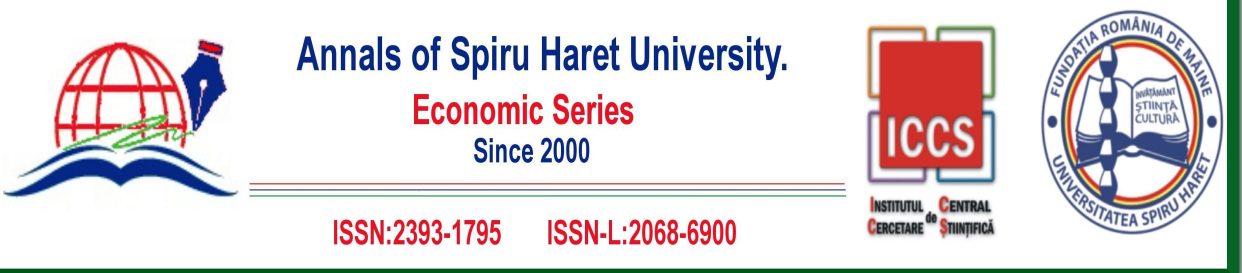

Issue 2/2019

The conception of the successful implementation of the national innovation policy

Characteristics of a national innovation policy

Public policy can be defined as the series or pattern of government activities or decisions designed to remedy certain social problems, as a purposeful course of action that an actor or the group of actors follows in dealing with a problem or matter of concern [Anderson, 2010; Khan \& Khandaker, 2016]. Innovation policy is one if its spheres.

Innovation policy as a term has become popular three decades before, but it does not mean, that it did not exist before. A policy, having innovation in the label to qualify (as innovation policy), started being popular from mid-1990s, but innovation policies as having an important impact (affect) on innovation may have existed for centuries [Edquist, 2004; Edquist, 2011; Edler \& Fagerberg, 2017]. Innovation policy is identified as public action that influences technical change and other kinds of innovations, therefore it has to go beyond science and technology (S\&T) policy (mainly focusing on stimulating basic science as a public good from the supply side) and to include elements of research and development (R\&D) policy, science policy, technology policy, infrastructure policy, regional policy and education policy, therefore this policy is named as science, technology and innovation (STI) policy [Edquist, 2001; Edle \& Fagerberg, 2017]. This complexity is one of the main characteristics of a national innovation policy.

Scholars distinguish main types (or frames) of innovation policy (see Table 1).

Table 1. Types of Innovation Policy

\begin{tabular}{|c|c|c|c|}
\hline Type & The core of the type & Requirements & Sources \\
\hline $\begin{array}{l}\text { Mission- } \\
\text { oriented } \\
\text { policies }\end{array}$ & $\begin{array}{l}\text { Aim at providing new solutions to } \\
\text { specific challenges that are on the } \\
\text { political agenda. } \\
\text { Policy-makers take into } \\
\text { consideration all phases of the } \\
\text { innovation process when designing } \\
\text { and implementing policy (broad } \\
\text { approach). }\end{array}$ & $\begin{array}{l}\text { Solutions must } \\
\text { work in } \\
\text { practice. }\end{array}$ & $\begin{array}{l}\text { Edler \& } \\
\text { Fagerberg, 2017; } \\
\text { Mowery, 2011; } \\
\text { Mazzucato, 2013; } \\
\text { Mazzucato \& } \\
\text { Semieniuk, 2017; } \\
\text { Florio et al., 2018 }\end{array}$ \\
\hline
\end{tabular}




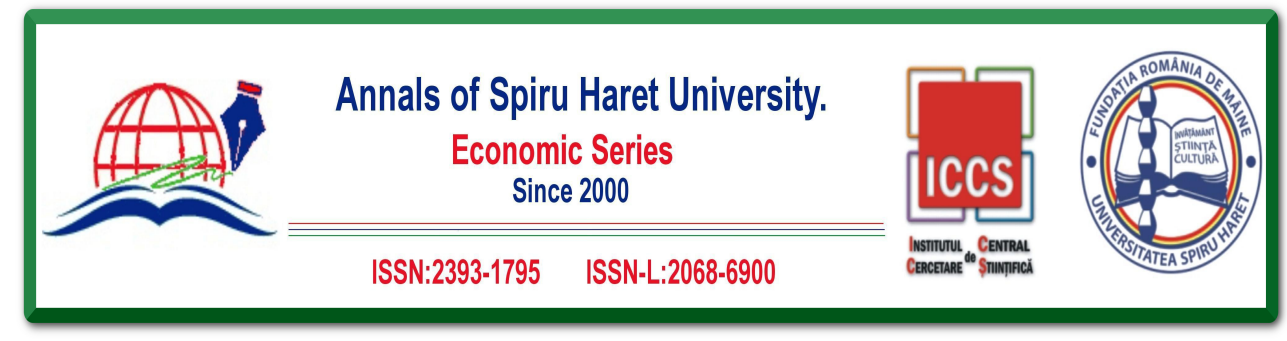

Issue 2/2019

\begin{tabular}{|c|c|c|c|}
\hline $\begin{array}{l}\text { Invention- } \\
\text { oriented } \\
\text { policies }\end{array}$ & $\begin{array}{l}\text { Concentrate on the R\&D/invention } \\
\text { phase, and leave the possible } \\
\text { exploitation and diffusion of the } \\
\text { invention to the market (narrow } \\
\text { approach). } \\
\text { Policy-makers belief in the } \\
\text { potential benefits of science and } \\
\text { technology that society might have. } \\
\text { Support considered as part of R\&D, } \\
\text { research, or science policy. }\end{array}$ & $\begin{array}{l}\text { Creation of new } \\
\text { public } \\
\text { organizations, } \\
\text { supporting firms } \\
\text { and public } \\
\text { research } \\
\text { organizations of } \\
\text { various types. }\end{array}$ & $\begin{array}{l}\text { Edler \& } \\
\text { Fagerberg, 2017; } \\
\text { Liotard \& Revest, } \\
2018 ; \\
\text { Florio et al., } 2018\end{array}$ \\
\hline $\begin{array}{l}\text { System- } \\
\text { oriented } \\
\text { policies }\end{array}$ & $\begin{array}{l}\text { Concentrate on the system-level } \\
\text { features, such as the degree of } \\
\text { interaction between different parts } \\
\text { of the system; the extent to which } \\
\text { some vital component of the system } \\
\text { is in need of improvement; or the } \\
\text { capabilities of the actors that take } \\
\text { part. } \\
\text { Policy must focus on building links, } \\
\text { clusters and networks, and on } \\
\text { stimulating learning between } \\
\text { elements in the systems, and } \\
\text { enabling entrepreneurship. }\end{array}$ & $\begin{array}{l}\text { The creation } \\
\text { and } \\
\text { development of } \\
\text { national } \\
\text { innovation } \\
\text { system (NIS). }\end{array}$ & $\begin{array}{l}\text { Edler \& } \\
\text { Fagerberg, 2017; } \\
\text { Ramstad, 2009; } \\
\text { Liotard \& Revest, } \\
2018 ; \\
\text { Florio et al., } \\
2018 ; \\
\text { Schot \& } \\
\text { Steinmueller, } \\
2018\end{array}$ \\
\hline $\begin{array}{l}\text { Transforma } \\
\text { tive change- } \\
\text { oriented } \\
\text { policies }\end{array}$ & $\begin{array}{l}\text { Its focus is on experimentation, and } \\
\text { the argument that the Global South } \\
\text { does not need to play catch-up to } \\
\text { follow the transformation model of } \\
\text { the Global North. } \\
\text { Connected to sustainable } \\
\text { development goals (ending poverty } \\
\text { and reducing inequality in all its } \\
\text { forms everywhere, promoting } \\
\text { inclusive and sustainable } \\
\text { consumption and production } \\
\text { systems, confronting climate } \\
\text { change, etc.). } \\
\text { Policy-makers are questioning how } \\
\text { to use science and technology }\end{array}$ & $\begin{array}{l}\text { Transformation } \\
\text { refers to socio- } \\
\text { technical system } \\
\text { change. }\end{array}$ & $\begin{array}{l}\text { Schot \& } \\
\text { Steinmueller, } \\
2018 ; \\
\text { Steward, 2012; } \\
\text { Weber \& } \\
\text { Rohracher, 2012; } \\
\text { Frenken, } 2017\end{array}$ \\
\hline
\end{tabular}




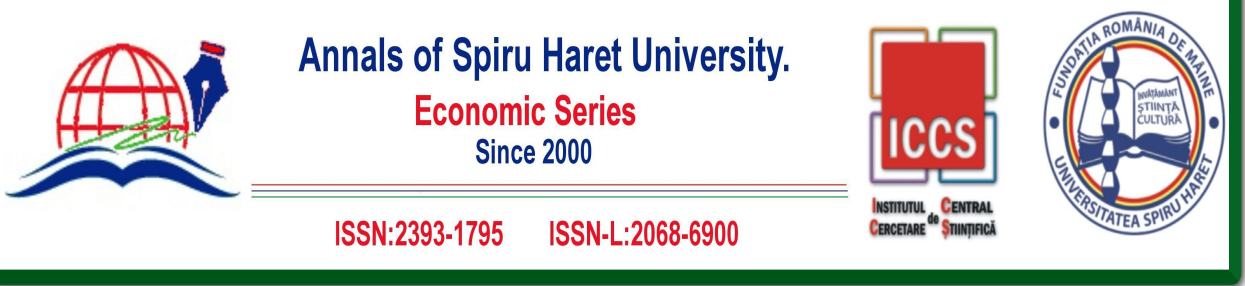

Issue 2/2019

\begin{tabular}{|l|l|l|l|}
\hline & $\begin{array}{l}\text { policy for meeting social needs and } \\
\text { address the issues of sustainable } \\
\text { and inclusive societies at a more } \\
\text { fundamental level or their } \\
\text { associated ideologies and practices. }\end{array}$ & & \\
\hline
\end{tabular}

Source: author's conducted on the basis of mentioned sources

All types of innovation policy can be adopted at a particular time, but in recent period system-oriented policies are most popular due to new tendencies and understanding of the importance of system-level features for countries wanting to gain a competitive advantage in the global market. However, transformative changeoriented policies are integrated in the national innovation policy due to the requirements from international organizations ( $\mathrm{UN}, \mathrm{OECD}$, etc.). Therefore, nowadays national innovation policy is oriented both to the system and the transformative change. It is the second characteristic of a national innovation policy.

The third characteristic of a national innovation policy is the specific of its instruments. The choice of instruments is the essential decision in the policy formulation stage. Scholars distinguish three types of instruments for a national innovation policy:

1. Regulatory instruments are tools that borrow from the routinized legal forms constituting the archetype of state interventionism, i.e. legal (state level) tools for the regulation of social and market interactions. The government seeks to define the framework of the interactions taking place in the society and in the economy, therefore NIS actors are obliged to act within some clearly defined boundaries. Examples of regulatory instruments are intellectual property rights, competition policy about R\&D alliances, bioethical regulations, etc.

2. Economic and financial instruments - specific pecuniary incentives (disincentives) and support for specific social and economic activities. The government can use economic means in cash or kind, and they can be based on positive incentives (encouraging, promoting certain activities, such as cash transfer, grants, subsidies, reduced-interest loans, loan guarantees, government or private provisions of goods and services, vouchers) or on disincentives (discouraging, restraining certain activities such as taxes, charges, fees, customs duties, tariffs). Therefore, national innovation policymakers usually use such instruments as support for research institutions and universities, competitive research funding, tax exemptions, support to venture and seed capital. 


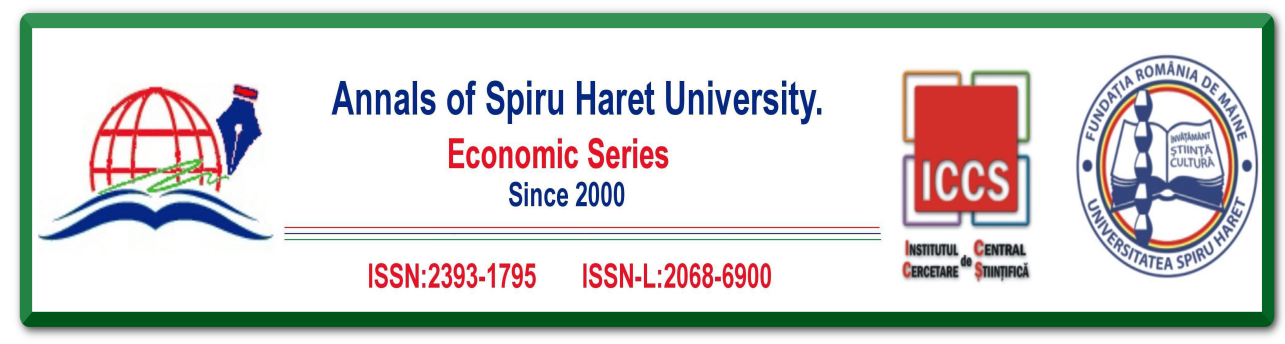

Issue 2/2019

3. Soft instruments - voluntary and non-coercive tools oriented to the organization of a different kind of relations, based on communication and consultation, helping to renew the foundations of legitimacy. It is not included to obligatory measures, sanctions or direct incentives, used by the government or public institutions. Examples of such instruments are voluntary standardisation, voluntary agreements and contractual relations, codes of conduct, campaigns, recommendations, public-private partnerships ([Lascoumes \& Le Galès, 2007; Borrás \& Edquist, 2013; Vedung, 2017].

The national innovation policy depends on the complex and integrations of different types of instruments on the particular time. According to some authors [Borrás \& Edquist, 2013], instruments are typically identified, chosen, designed and implemented with a specific problem in mind, in a specific innovation policy context, at a specific point in time, and in a specific political-ideological situation of the government, therefore, the strong contextual nature of the choice and specification of national innovation policy instruments is a crucial aspect in the design and use of policy tools. Besides, goals, tasks and instruments must meet the needs of a particular socio-economic situation in a country due to the need for the success of their implementation in a national innovation system.

\section{Successful implementation of the national innovation policy}

Implementation of the public policy is defined as the ability to forge subsequent links in the causal chain so as to obtain the desired results, or the carrying out of a basic policy decision, usually incorporated in a statute but which can also take the form of important executive orders or decisions [Signé, 2017]. So the implementation is a very important stage in the innovation policy-making process. It can be considered as a process, output and outcome, which refers to the execution of law, in which various actors (stakeholders, organisations, institutions) work together with the use of procedures and techniques to put policies into effect to help attain goals of innovation progress [Stewart, 1998; Khan \& Khandaker, 2016].

However, relevant design of national innovation policy is not the guarantee for the successful implementation. It can be followed by failures to meet its intended goals and/or can be hampered by implementation challenges. This implementation 'gap' between aspiration and reality is a frustrating scenario, despite of significant sources and attention put into designing policies (policy-making process) [Moon et al., 2017]. Successful policy implementation (outputs) depends not only on designing effective systems (such as NIS), but also on managing their implementation 


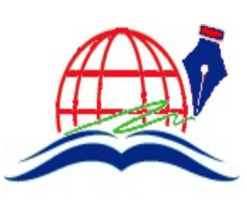

Annals of Spiru Haret University.

Economic Series

Since 2000
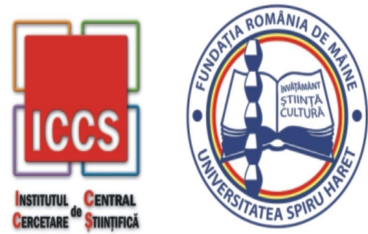

Issue 2/2019

[Brinkerhoff \& Crosby, 2002; Khan \& Khandaker, 2016]. Consequently, main factors acting as stimulus and barriers in the process of the national innovation policy implementation must be identified.

Table 2. Models for the Successful Policy Implementation

\begin{tabular}{|c|c|c|c|c|c|}
\hline $\begin{array}{l}\text { Mo } \\
\text { del }\end{array}$ & Rational Model & Management Model & $\begin{array}{c}\text { Organisational } \\
\text { Development Model }\end{array}$ & $\begin{array}{c}\text { Bureaucratic } \\
\text { Model }\end{array}$ & Political Model \\
\hline 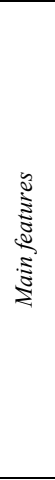 & $\begin{array}{l}\text { 1. Clarity of policy } \\
\text { goals, targets and } \\
\text { objectives; } \\
\text { 2. Accurate and } \\
\text { consistent planning; } \\
\text { 3. Clear and } \\
\text { detailed task } \\
\text { assignments; } \\
\text { 4. Accurate } \\
\text { standardisation; } \\
\text { 5. Proper } \\
\text { monitoring. }\end{array}$ & $\begin{array}{l}\text { 1. Sufficient and } \\
\text { effective use of } \\
\text { budget; } \\
\text { 2. Right } \\
\text { organisational } \\
\text { structure; } \\
\text { 3. Quick, clear and } \\
\text { two-way } \\
\text { communication; } \\
\text { 4. Involvement of } \\
\text { people as co- } \\
\text { producers; } \\
\text { 5. Adequate } \\
\text { equipment and } \\
\text { appropriate } \\
\text { technology; } \\
\text { 6. Correct location. }\end{array}$ & $\begin{array}{l}\text { 1. Effective leadership; } \\
\text { 2. Motivation; } \\
\text { 3. Engagement of people; } \\
\text { 4. Team building; } \\
\text { 5. Accuracy of decisions. }\end{array}$ & $\begin{array}{l}\text { 1. Proper } \\
\text { discretion of } \\
\text { frontline } \\
\text { implementers; } \\
\text { 2. Competency of } \\
\text { front-line } \\
\text { implementers; } \\
\text { 3. Control of the } \\
\text { behaviour of } \\
\text { front-line } \\
\text { implementers; } \\
\text { 4. Commitment } \\
\text { of front-line } \\
\text { implementers. }\end{array}$ & $\begin{array}{l}\text { 1. Avoiding } \\
\text { complexity of } \\
\text { joint actions; } \\
2 . \quad \text { Higher } \\
\text { bargaining } \\
\text { capacity; } \\
\text { 3. Harmony } \\
\text { among political } \\
\text { actors; } \\
\text { 4. Active } \\
\text { political } \\
\text { motivation; } \\
5 . \quad \text { Minimising } \\
\text { the influence of } \\
\text { pressure politics. }\end{array}$ \\
\hline 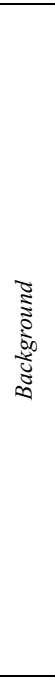 & $\begin{array}{l}\text { Implementation } \\
\text { depends on: } \\
\text { - the clarification } \\
\text { of goals, missions } \\
\text { and objectives, } \\
-\quad \text { detailed } \\
\text { planning, } \\
-\quad \text { appropriate job } \\
\text { assignments, } \\
\text { - effective } \\
\text { monitoring and } \\
\text { evaluation, } \\
-\quad \text { comprehensive } \\
\text { and } \\
-\quad \text { efficient } \\
\text { operating } \\
\text { procedures, } \\
\text { - techniques } \\
\text { required to assist } \\
\text { implementers to } \\
\text { define the scope of } \\
\text { their responsibilities } \\
\text { in line with policy } \\
\text { objectives. }\end{array}$ & $\begin{array}{l}\text { Implementation } \\
\text { depends on: } \\
-\quad \text { organisational } \\
\text { structure, } \\
-\quad \text { personnel and } \\
\text { human resources, } \\
-\quad \text { the activities of } \\
\text { front-line } \\
\text { implementers, } \\
-\quad \text { equipment and } \\
\text { technology, } \\
-\quad \text { the level of } \\
\text { coordination and } \\
\text { cooperation, } \\
-\quad \text { the exercise of } \\
\text { authority, and } \\
\text { place/location as } \\
\text { implementation } \\
\text { infrastructure. }\end{array}$ & $\begin{array}{l}\text { Implementation depends } \\
\text { on: } \\
\text { - organisational } \\
\text { leadership capacity, } \\
\text { - team building, } \\
\text { - the engagement of the } \\
\text { various parties involved, } \\
\text { - participation, } \\
\text { - motivation, } \\
\text { coordination, } \\
\text { - commitment }\end{array}$ & $\begin{array}{l}\text { Implementation } \\
\text { relies heavily on: } \\
\text { - the role of } \\
\text { members of staff } \\
\text { who directly come } \\
\text { into contact with } \\
\text { people and other } \\
\text { stakeholders. }\end{array}$ & $\begin{array}{l}\text { Implementation } \\
\text { depends on: } \\
\text { - the outcome } \\
\text { of interactions } \\
\text { between agent } \\
\text { capacity, } \\
\text { - institutional } \\
\text { or representative, } \\
\text { bargaining } \\
\text { power, } \\
\text { - conflict } \\
\text { resolution, } \\
\text { - outside } \\
\text { environmental } \\
\text { factors from an } \\
\text { economic, } \\
\text { political and } \\
\text { social } \\
\text { perspective. }\end{array}$ \\
\hline
\end{tabular}




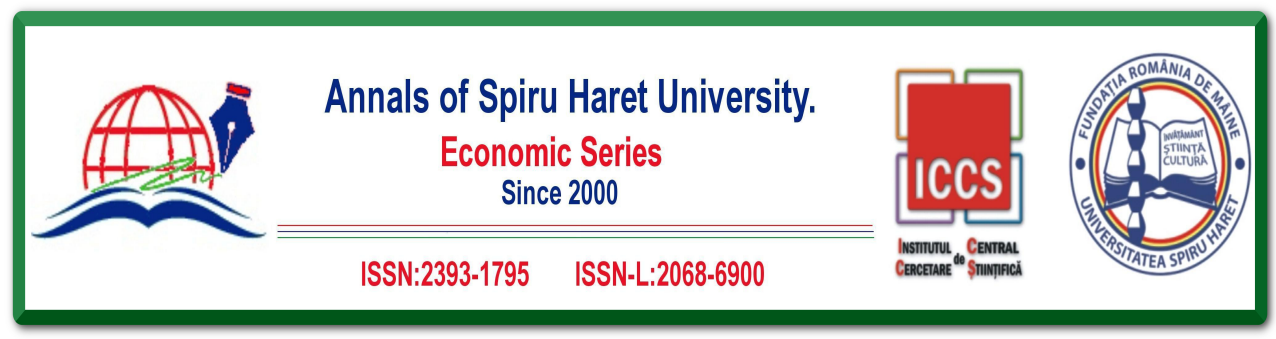

Issue 2/2019

\begin{tabular}{|c|c|c|c|c|c|}
\hline 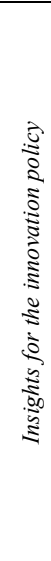 & $\begin{array}{l}\text { Stimulus: Clear } \\
\text { declaration of goals } \\
\text { helps to identify } \\
\text { areas to develop, } \\
\text { instruments to use, } \\
\text { actors to involve, } \\
\text { reasonable and } \\
\text { weighted solutions } \\
\text { to make. Top-down } \\
\text { approach. } \\
\text { Barriers: the } \\
\text { standardisation or } \\
\text { blind following of } \\
\text { guidelines or good } \\
\text { practice can miss } \\
\text { some specifics of the } \\
\text { particular NIS, time } \\
\text { or socio-economic } \\
\text { context. }\end{array}$ & $\begin{array}{l}\text { Stimulus: this model is } \\
\text { following principles of } \\
\text { New Public } \\
\text { Management and } \\
\text { leads to effectiveness } \\
\text { and efficiency. } \\
\text { Barriers: the shortage } \\
\text { of resources or delays } \\
\text { to resource acquisition } \\
\text { can cause many } \\
\text { problems for the NIS. }\end{array}$ & $\begin{array}{l}\text { Stimulus: this policy } \\
\text { involves more actors of } \\
\text { the NIS to the policy } \\
\text { implementation process } \\
\text { and creates trust links } \\
\text { between them. } \\
\text { Barriers: as it depends } \\
\text { mostly on human } \\
\text { resources and } \\
\text { organizational behaviour } \\
\text { the model adaptation can } \\
\text { be longer and more } \\
\text { complex process. Besides } \\
\text { it is more convenient for } \\
\text { smaller systems than a } \\
\text { NIS. }\end{array}$ & $\begin{array}{l}\text { Stimulus: this } \\
\text { model is intended } \\
\text { to ascertain social } \\
\text { reality with regard } \\
\text { to the } \\
\text { discretionary } \\
\text { power of front- } \\
\text { line } \\
\text { implementers; the } \\
\text { model is based on } \\
\text { the bottom-up } \\
\text { policy } \\
\text { implementation. } \\
\text { Barriers: } \\
\text { positions of front- } \\
\text { line implementers } \\
\text { can be different } \\
\text { from other } \\
\text { participants of a } \\
\text { NIS. }\end{array}$ & $\begin{array}{l}\text { Stimulus: the } \\
\text { interplay among } \\
\text { agencies, actors } \\
\text { and interest } \\
\text { groups in a NIS. } \\
\text { Barriers: policy } \\
\text { is an outcome of } \\
\text { the degree of } \\
\text { conflict and the } \\
\text { efficiency } \\
\text { of conflict } \\
\text { management in a } \\
\text { NIS (weak } \\
\text { capacity of } \\
\text { conflict } \\
\text { management can } \\
\text { lead to the } \\
\text { failure). }\end{array}$ \\
\hline
\end{tabular}

Source: author's conducted according to Khan \& Khandaker (2016), Pülzl \& Treib (2006), Zhang \& Bratol (2010), Tummers \& Bekkers (2014)

The analysis of the scientific literature revealed that five different models for the successful implementation of public policy are distinguished. All of them can be adapted to the field of innovation policy (see Table 2).

While analysing the national innovation policy as a part of country's public policy aiming to the socio-economic progress, the rational model is considered as the main one: policy objectives are set out by central policy makers; adequate bureaucratic procedures are established to ensure that policy is executed as accurately as possible; implementing agencies have sufficient resources at their disposal; and there is a need to be a system (NIS) of clear responsibilities and control to supervise the actions of implementers [Pülzl \& Treib, 2006]. This theoretical approach is consistent with the system-oriented and transformative change-oriented policy as the national innovation policy must be. It is connected with the IPO (input-process-output) model, which is very relevant for the explanation of system activities and results [Curral et al., 2001; West et al., 2004; Carayannis \& Provance, 2008; Hitt et al., 2011; etc.]. Besides, this rational model is supported by other researches in the field of successful implementation of innovation policy. It relies on five main factors affecting successful implementation: clarity and logical consistence of objectives; structured process; committed implementers; adequate resources; excellent communication and 


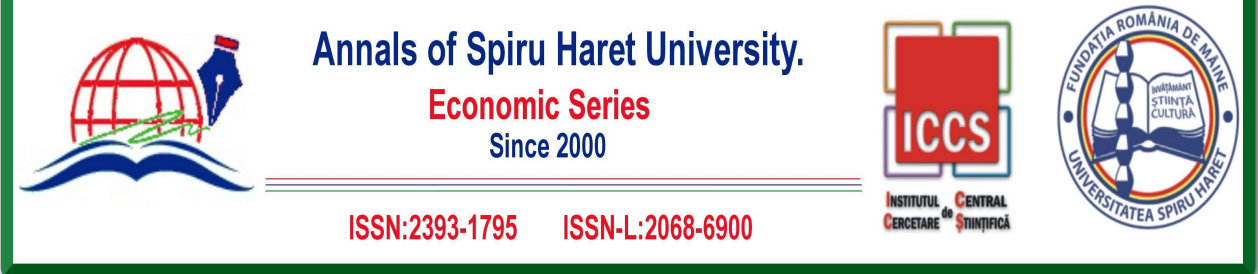

Issue 2/2019

coordination [Bitrán, 2017; Singh, 2017]. This theoretical approach was taken as the main one for the empirical research of Lithuanian innovation policy, trying to identify factors' reflection in the implementation of small developed country's innovation policy.

\section{Methods of the research}

The empirical research is based on theoretical implications of the rational model for the successful implementation of public policy [Khan \& Khandaker, 2016; Pülzl \& Treib, 2006; Bitrán, 2017; Singh, 2017]; consequently, five elements of the implementation of Lithuanian innovation policy are analyzed: objectives; process; implementers; resources; communication and coordination.

Based on the theoretical approach that the rational model is adopted rather as a prescriptive model (advice on possible outcomes) than as an analytical device [Parsons, 2006], few scientific methods of the research were used:

- Document analysis. It is a systematic procedure for reviewing or evaluating documents, it requires that data be examined and interpreted in order to elicit meaning, gain understanding, and develop empirical knowledge [Corbin \& Strauss, 2008; Bowen, 2009]. The analysis included national legal documents (National Progress Strategy "Lithuania 2030" and Lithuanian Innovation Development Programme 2014-2020, other national documents and public sources) with the aim to reveal objectives process, implementers, communication and coordination of Lithuanian innovation policy.

- Secondary data analysis. It is the analysis of data that was collected by someone else for another primary purpose and it provides a viable option for researchers limited by time and resources [Johnston, 2014]. This research has used data and its channels of European Commission (ec.europa.eu), The Lithuanian Department of Statistics (Statistics Lithuania) (stat.gov.lt), and other sources to reveal the situation of resources, needed and used for the national innovation policy.

- Summarizing, interpretation. Methods used in the document analysis and secondary data analysis, helping identify main insights of the empirical research and to explain links between theoretical and empirical findings.

The empirical research was conducted from the October 2018 to the January 2019. 


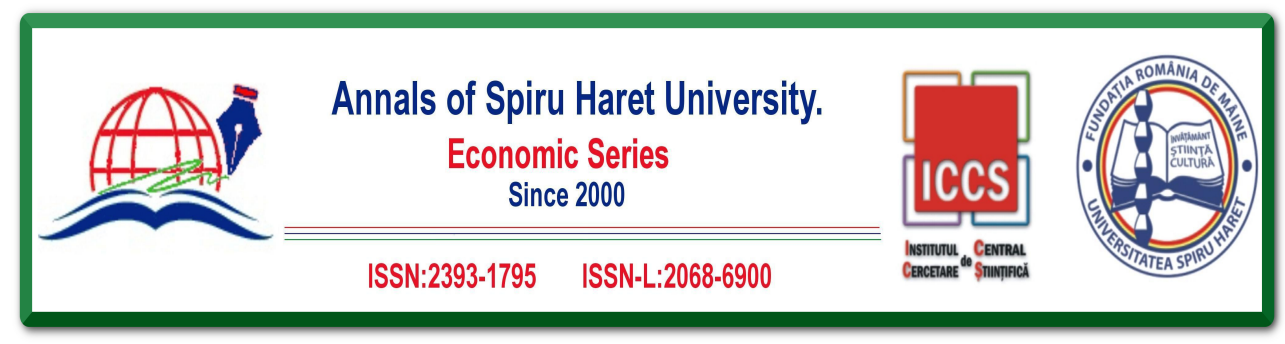

Issue 2/2019

\section{Results}

Five factors of the rational model are used to analyse the success of the implementation of the Lithuanian innovation policy. The results are presented according to this approach.

\section{Clarity and logical consistence of objectives}

As it was mentioned before that to achieve successful outcomes of the national innovation policy main goals and objectives must be clearly and logically declared.

Lithuania's Progress Strategy "Lithuania 2030" (2012) has declared the vision of the state - "Lithuania is a smart country: a good place to live and work" based on such progress-relevant values as openness, creativity and responsibility. All those values are explained and directly (first two values) or indirectly (the third one) mention innovations or innovative activities. This state vision is based on three main areas too: smart society, smart economy and smart governance [smartness of the society and economy are explained through the point of innovations, smartness of the governance is linked to high quality services which requires new technological and social solutions (innovations)]. Innovation policy as a term is mentioned just once in this document while explaining the task for the smart economy "We need to encourage the set-up of international companies and scientific research and service centres in Lithuania. This will not only guarantee high-paying jobs and halting brain drain and emigration, but also will play a very important role as catalysts for change, by bringing to Lithuania the leading world trends, modern technologies as well as challenging the public education and innovation policy and business conditions". But there is no any clarification of measures, tools or instruments, explaining possibilities to implement such a task.

Lithuanian Innovation Development Programme 2014-2020 (2013) is the document with the legal power, playing the role of guidelines for the implementation of the national innovation policy. The main goal of Lithuanian innovation policy is "to enhance the competitiveness of Lithuanian economy by creating effective innovation system, promoting the innovativeness". The goal is followed by objectives:

- "to develop innovative society by developing new knowledge and its application;

- to enhance innovation potential of business;

- to promote the creation, development and internationalization of value networks;

- to increase efficiency of innovation policy-making and implementation and promote innovations in the public sector". 


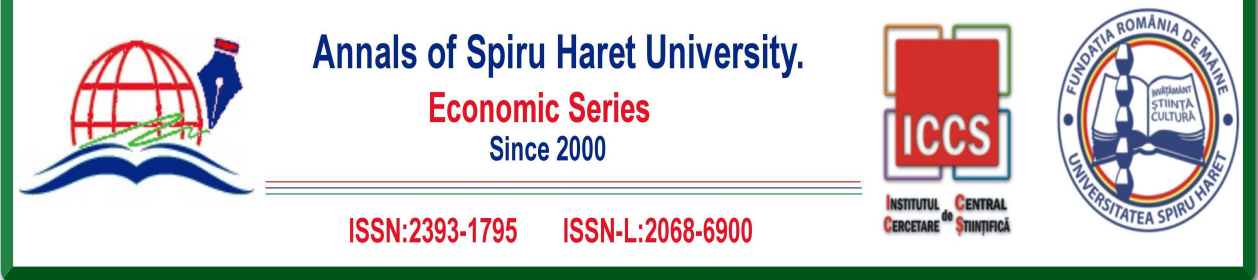

Issue 2/2019

Such objectives clarify that the national innovation policy must enable all three types of instruments (regulatory, economic and financial and soft) in Lithuania. Very important role of soft instruments can be identified due to the need of changing society's mindset to the smartness and innovativeness.

Lithuanian Innovation Development Programme 2014-2020 (2013) has identified the smart specialization as the main priority and named six fields to plan the process of the implementation of the national innovation policy: "Energy and a sustainable environment", "Inclusive and creative society", "Agro-innovation and food technologies", "New production processes, materials and technologies", "Health technologies and biotechnologies", "Transport, logistic and information and communication technologies". Despite of the understanding that the NIS can cover quite broad range of fields, the main direction of Lithuania's smart specialization and its development still remains unclear due to the wide range of spheres where the national progress is planned. Besides, sometimes actors of the NIS miss clear longterm direction of Lithuanian innovation policy to be sure about continuing funding, support and other help for the business development [Juknevičienè, 2015].

According to mentioned strategic documents, objectives of national innovation policy are quite clear and logical - to develop the knowledge-based business and the knowledge-based society, to strengthen networking and to ensure the efficiency. It should stimulate the successful implementation of the innovation policy.

\section{Structured process}

Results of a NIS can be measured on the basis of IPO (input-process-output) model, however the element of the process is always more complicated to explain and evaluate. Despite of the fact, the structured process plays very important role for the successful implementation. To understand it, NIS actors and their activities, strengthening the innovativeness, must be named.

NIS explanation is based on the Triple Helix model - the constant interaction between actors (Science-Business-Governance institutions) [Etzkowitz \& Leydesdorff, 2000; Etzkowitz, 2007; Juknevičienè, 2015]. The promotion of innovativeness can explain what kind of processes are working and how they are structured in a NIS. Therefore, the promotion of innovativeness must be done in all three dimensions (see Table 3). 

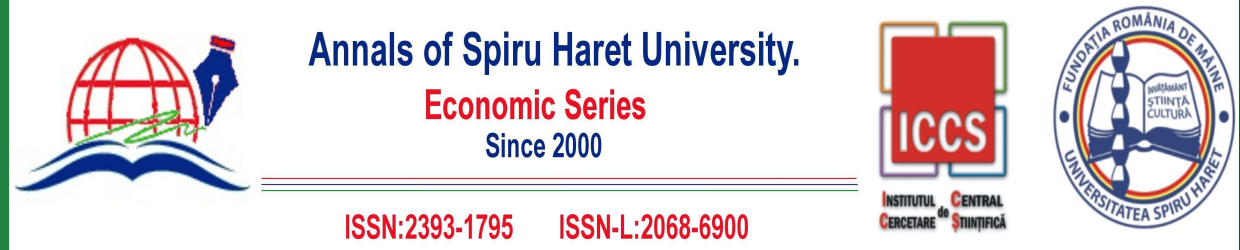

Issue 2/2019

Table 3. Promotion of Innovativeness in Lithuania

\begin{tabular}{|c|c|c|}
\hline $\begin{array}{c}\text { The } \\
\text { dimension of } \\
\text { Triple Helix } \\
\text { model }\end{array}$ & Newest changes in Lithuanian NIS until 2019 & Actors of a NIS \\
\hline $\begin{array}{l}\text { Science and } \\
\text { High } \\
\text { Education }\end{array}$ & $\begin{array}{l}\text { - New focus of education system to physical and natural sciences } \\
\text { (informatics, mathematics, physics, robotics, biology, chemistry) } \\
\text { seeking to educate skills needed for engineering potential; } \\
\text { - More attention for the same focus on specific programs of } \\
\text { informal education; } \\
\text { - More attention and funding for studies and researches of } \\
\text { physical and natural sciences (reducing attention on humanities } \\
\text { and social sciences); } \\
\text { - Possibility to commercialize products, created in universities, } \\
\text { institutes (established agreements of copyrights). }\end{array}$ & $\begin{array}{l}\text { Universities, research } \\
\text { institutes, universities of } \\
\text { applied sciences. } \\
\text { Support institutions } \\
\text { Government }\end{array}$ \\
\hline Business & $\begin{array}{l}\text { - Special funding programs for cooperation with science, for } \\
\text { innovations, for start-ups. } \\
\text { - Changing attitude to universities, possibility to commercialize } \\
\text { products together; } \\
\text { - Business initiatives and ideas, connected to social } \\
\text { responsibility. }\end{array}$ & $\begin{array}{l}\text { Global enterprises, small } \\
\text { and medium firms. } \\
\text { Support institutions } \\
\text { Government, universities, } \\
\text { research institutes }\end{array}$ \\
\hline \multirow[t]{2}{*}{ Governance } & $\begin{array}{l}\text { - Innovation vouchers, } \\
\text { - Innovative public procurement and pre-commercial } \\
\text { procurement, } \\
\text { - Information/Consultations, } \\
\text { - Tax incentives. }\end{array}$ & $\begin{array}{l}\text { Ministry of Economy } \\
\text { Support institutions }\end{array}$ \\
\hline & $\begin{array}{l}\text { - Reforming high education and professional education systems } \\
\text { - New document "Regulation for the annual evaluation of } \\
\text { research and experimental development and the arts activities by } \\
\text { universities and research institutes" (2017-10-04) - focus for } \\
\text { highest quality of scientific production, funding high education } \\
\text { according R\&D results (the shift of the science quality } \\
\text { orientation). }\end{array}$ & $\begin{array}{l}\text { Ministry of Education and } \\
\text { Science } \\
\text { Support institutions } \\
\text { Universities, other high } \\
\text { education institutions, } \\
\text { research institutes }\end{array}$ \\
\hline
\end{tabular}

Source: author's conducted

All actors in a NIS are involved in the process of the implementation of the national innovation policy (to the Triple Helix). It is done via direct or indirect activities, links, and communication. New trends of innovation policy influence innovative activities of all NIS actors as well as their behaviour and solutions. Changes and complexity of the activity in a NIS complicate the structuring of 


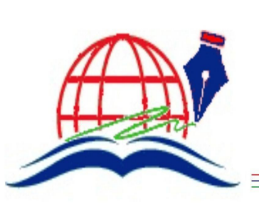

Annals of Spiru Haret University.

Economic Series

Since 2000

ISSN:2393-1795

ISSN-L:2068-6900
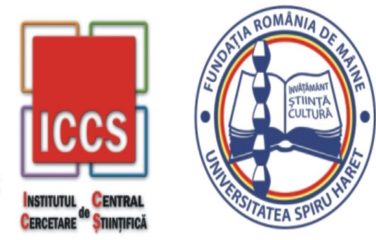

Issue 2/2019

processes; therefore, it can become a barrier for the successful implementation of the national innovation policy.

\section{Committed implementers}

Even the Triple Helix model is oriented to three main dimensions of actors in a NIS (university-business-government), Lithuanian IS has the specific that it has four dimensions (see Fig. 1).

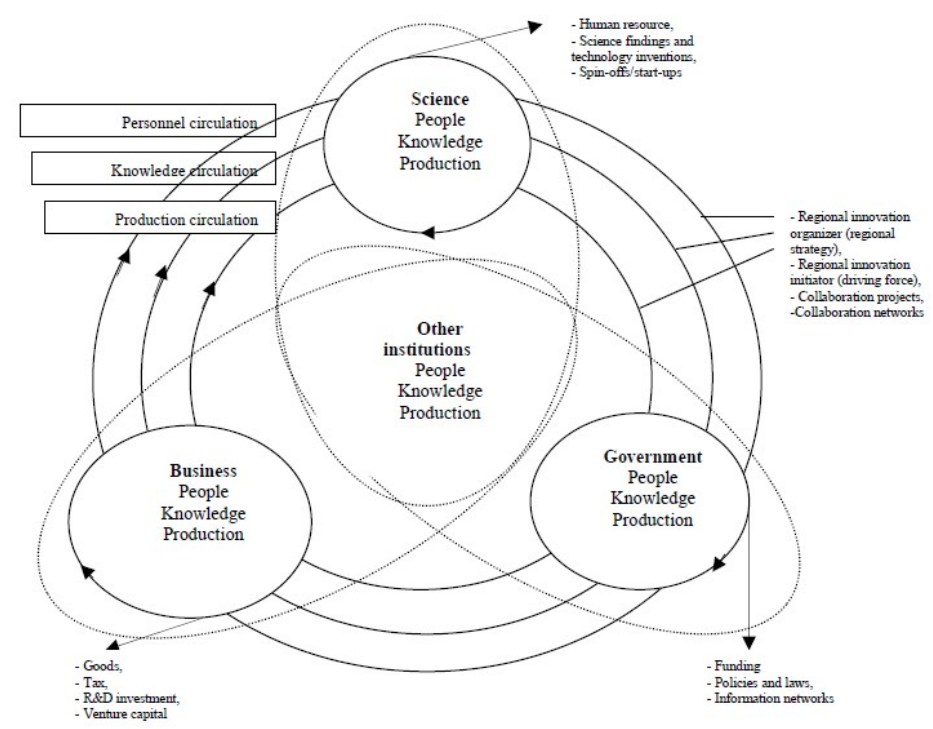

Fig. 1. Triple Helix Model in the Context of Lithuania Source: adapted from Etzkowitz (2007, pp. 9)

Those four dimensions of Lithuanian IS are: science (universities, universities of applied sciences, research institutes), business (enterprises), governance (ministries of economy and education and science, coordinating innovation policy), business and innovation support [special governmental agencies such as MITA (Agency for Science, Innovation and Technology) and LIC (Lithuanian Innovation Centre), PI "Investuok Lietuvoje (Invest in Lithuania)", PI "Versli Lietuva (Enterprise 

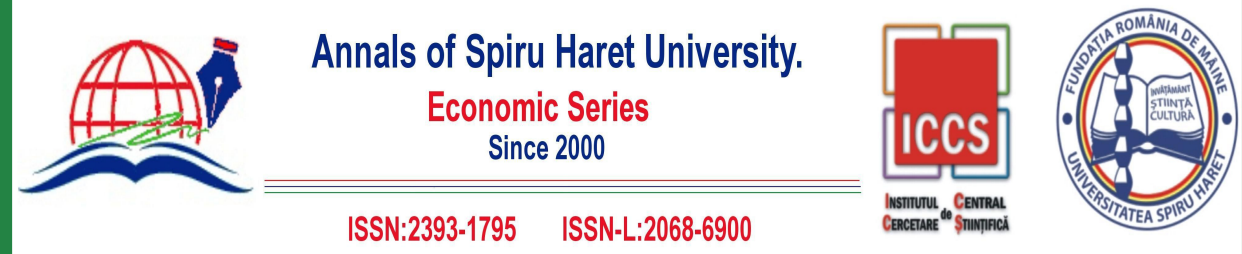

Issue 2/2019

Lithuania)", etc.], integrated science, studies and business centres (5 valleys), science and technology parks (9), innovation centres, industrial parks (4), free economic zones (2), etc.), all paying the role of intermediating and helping to ensure the continuous and long-term processes of the implementation of innovation policy via funding, consultation and information processes.

The infrastructure of NIS (actors) is quite rich one, including science2science, science2business, governement2business, government2science, business2business institutions. But the problem is that the establishment of some support institutions has not given expected result for the economic growth or even was unprofitable and lossmaking solutions (especially it is connected to valleys and science and technology parks, open access centres). Therefore, it is expected that the Lithuanian system of committed implementers of innovation policy will change in close future. However, the role of implementers in a NIS cannot be evaluated as a stimulus or barrier at this particular period.

\section{Adequate resources}

Each policy implementation must be equipped by needed human and material resources. National innovation policy in Lithuania is not the exception.

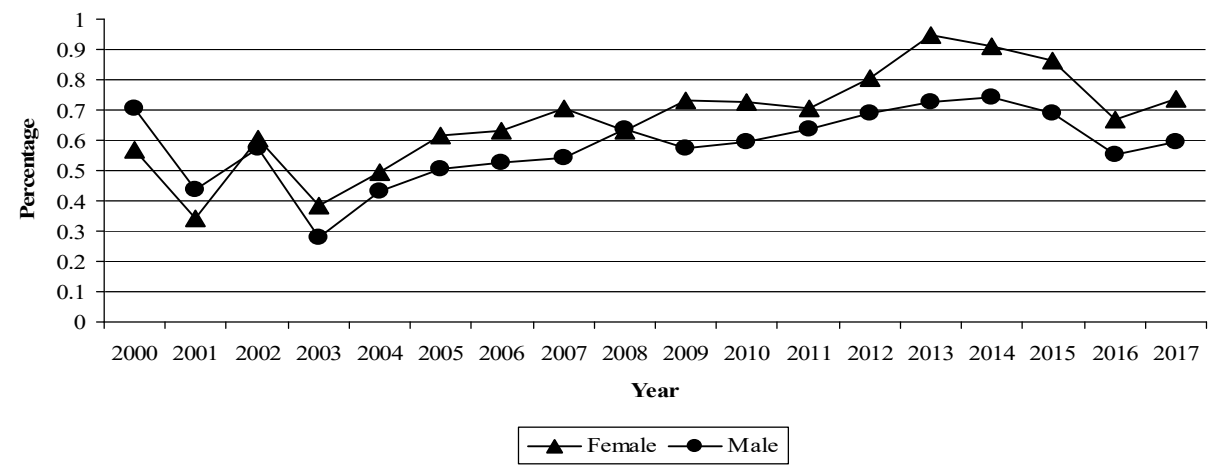

Fig. 2. New Doctoral Graduates per Thousand Population Aged 25-34 in Lithuania Source: author's conducted based on European Commission, New doctoral graduates per thousand population aged 25-34 (2019)

Despite of well-known demographic challenges for Lithuania (such as huge emigration ratio, especially of young labour force), the NIS needs professionals to 


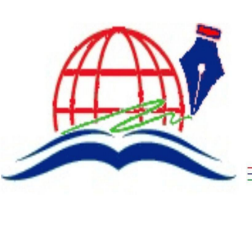

Annals of Spiru Haret University.

Economic Series

Since 2000
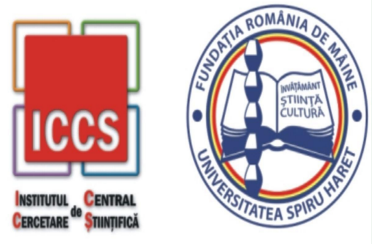

\section{Issue 2/2019}

create and exploit innovations. Therefore, it is needed to provide the particular number of educated professionals for the Lithuanian market.

Innovations usually require specific skills and knowledge, i.e. educated human resources. Consistently, indicators of doctoral graduates and their employment in science and technology field play a crucial role for the evaluation of innovative potential in a NIS. It was identified, that despite of the constant growing need for professionals with tertiary education in Lithuanian market (from 2003), the number of doctoral graduates is reducing in recent 5 years (from 2013) (see Fig. 2, Fig. 3).

According to the Community Innovation Survey (CIS) (2015) the proportion of innovative enterprises fell below 50 percent in the EU in 2010-2012. In Lithuania this indicator has the tendency of fluctuation (30.3 percent in 2006-2008, 34.5 percent in 2008-2010, 32.5 percent in 2010-2012), but it lags behind the European average (respectively $51.5,52.8$ and 48.9 percent).

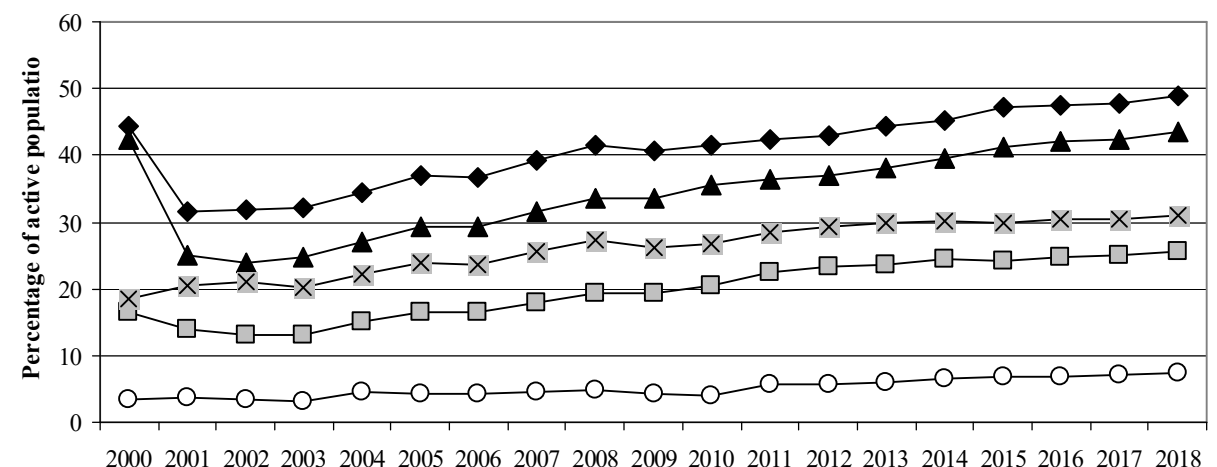

Year

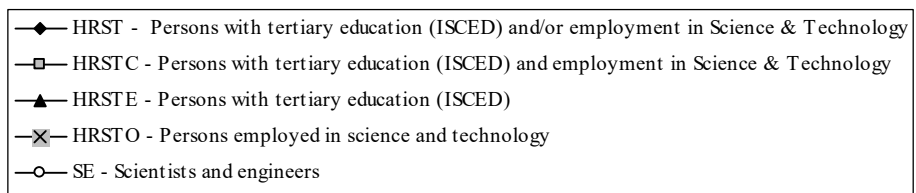

Fig. 3. Human Resources in Science and Technology (HRST) by Sub-Groups in Lithuania

Source: author's conducted based on European Commission, Human resources in science and technology (HRST) by sub-groups (2019) 


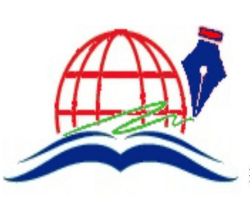

\section{Annals of Spiru Haret University.}

Economic Series

Since 2000
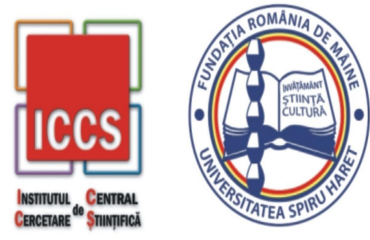

Issue 2/2019

The other important issue for the implementation of innovation policy is the need for material resources (see Fig. 4, Fig. 5, Fig. 6 and Fig. 7).

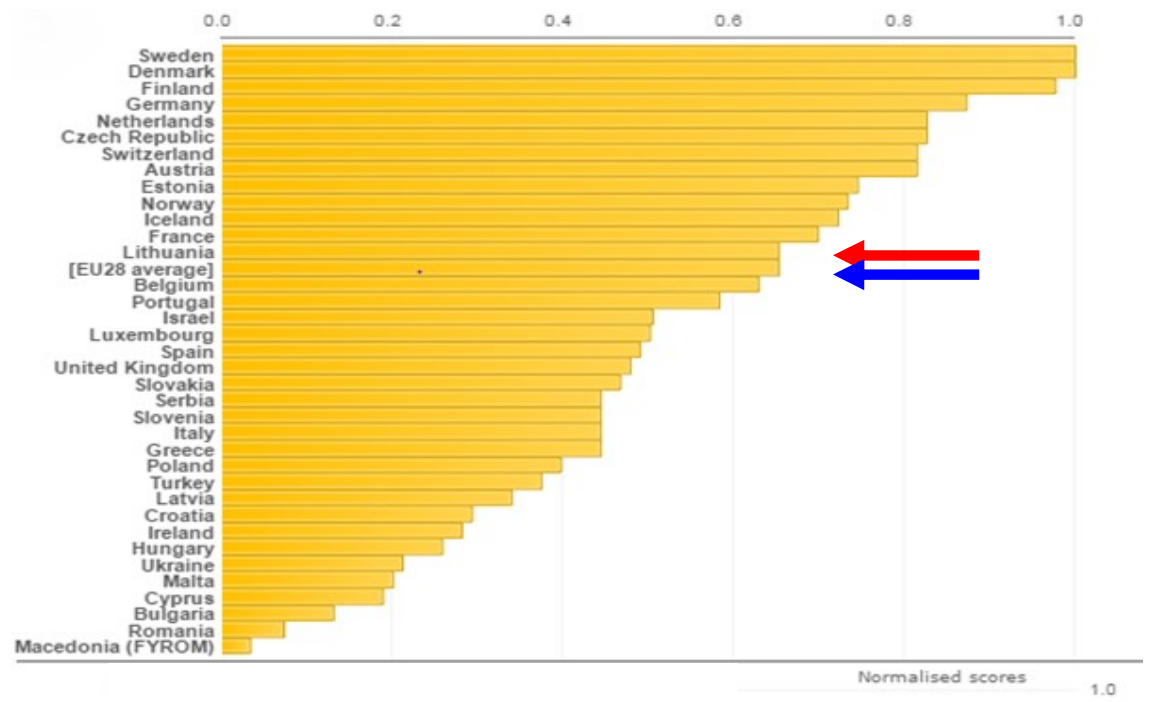

Fig. 4. Public R\&D funding, 2016

Source: author's adapted from Levanti (2016)

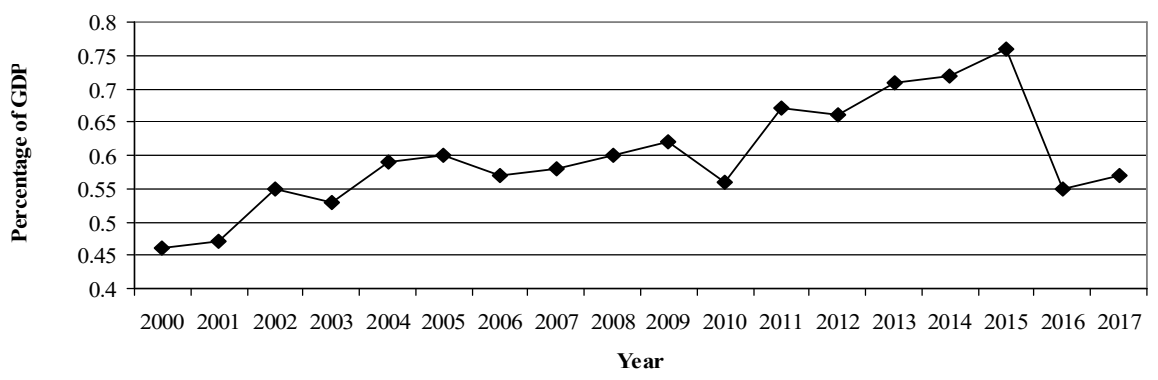

Fig. 5. Public (Government and Higher Education) R\&D Expenditure as \% of GDP

Source: author's conducted based on, European Commission, Public (government and higher education) $R \& D$ expenditure as \% of GDP - Lithuania (2019) 


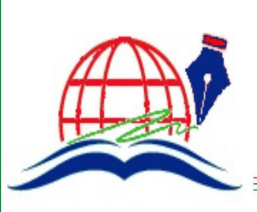

Annals of Spiru Haret University.

Economic Series

Since 2000

ISSN:2393-1795

ISSN-L:2068-6900
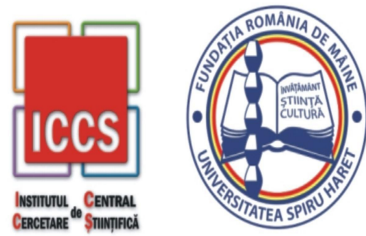

Issue 2/2019

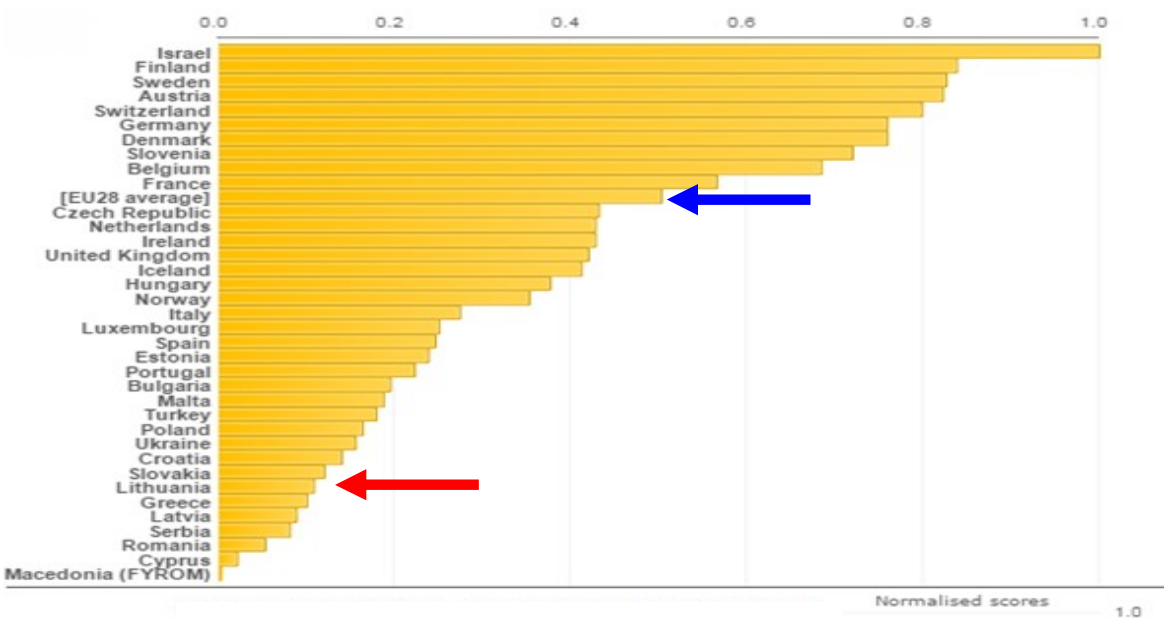

Fig. 6. Public R\&D funding, 2016

Source: author's adapted from Levanti (2016)

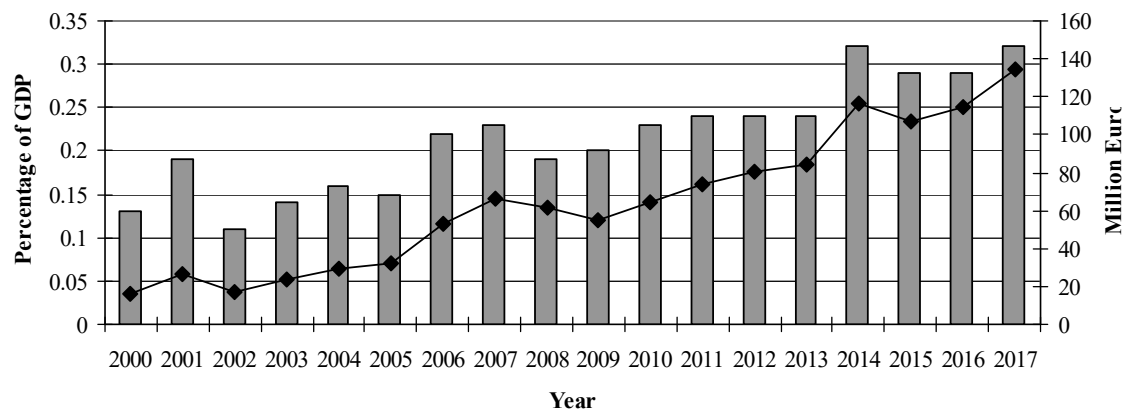

Fig. 7. Private Enterprise Expenditure on R\&D (Absolute Value and Intensity)

Source: author's conducted based on, European Commission, Private Enterprise

Expenditure on R\&D (absolute value and intensity) - Lithuania (2019)

The analysis of data has revealed the interesting phenomenon of inputs in the performance of the Lithuanian NIS. The low public R\&D expenditures in 2016 were influenced by the ending and starting new period of EU funding, which have struggled due to some administrative reasons. Despite of this and the fact that public 42 

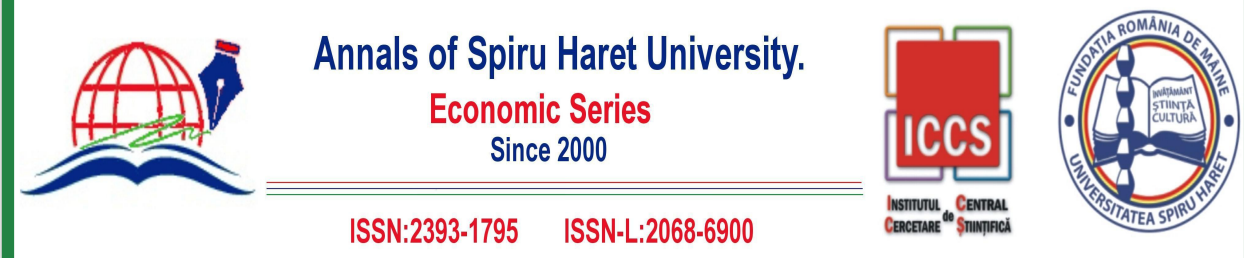

Issue 2/2019

R\&D funding in 2016 was quite low (equal to the level of funding in 2003), it still has matched to the level of public R\&D funding of EU 28 average and was quite high in comparison to the level of other EU states. It means that innovative activities in Lithuania are vitally depended on public funding (from national and EU budgets). However, private R\&D funding is not so popular. And even the total sum of private investments to R\&D activities (enterprise expenditures) are constantly growing, it is considered as very low one in comparison to other EU 28 states. This leads to the assumption, that private R\&D expenditures in Lithuania are low. But the "grey zone" of R\&D investments must be mentioned here - some enterprises avoiding any mistakes in the accounting of taxes (due to taxes discounts for enterprises implementing $R \& D$ activities) avoid declaring research and development activities and implementing it under the title of regular firm's activity. In this case it is impossible to make any statistical evaluation of real R\&D expenditures in the field of business.

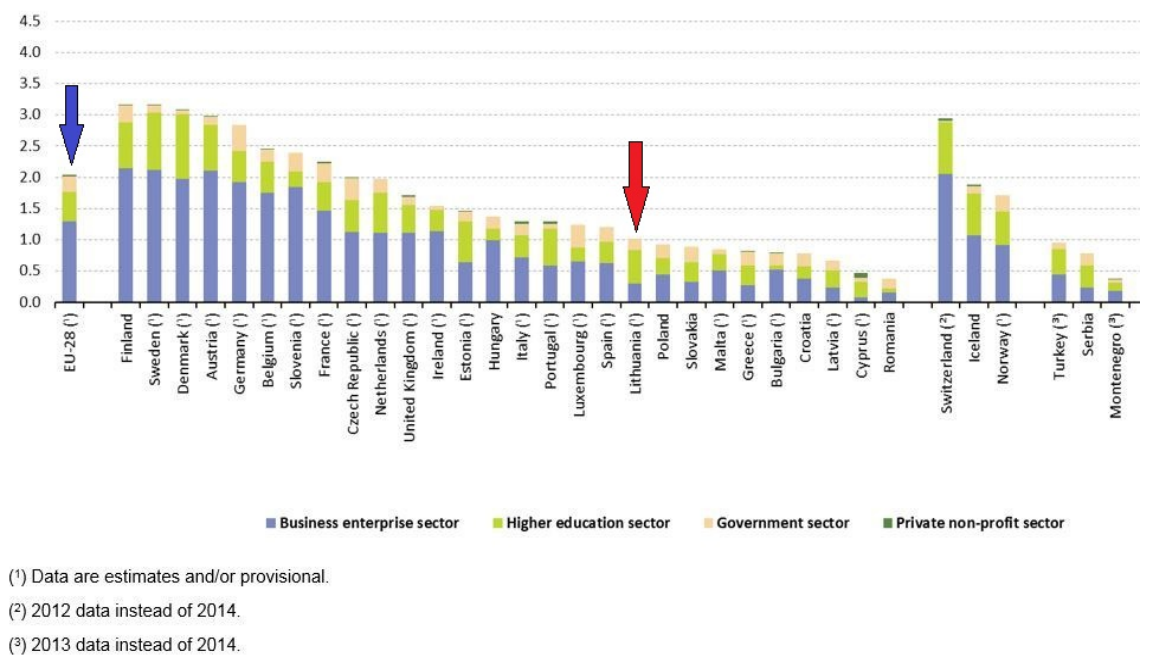

Fig. 8. Gross Domestic Expenditure on R\&D, by Sectors of Performance, by Country, 2016

Source: author's adapted from Eurostat, Gross domestic expenditure on $R \& D$, by sectors of performance, by country, 2016 (2019) 

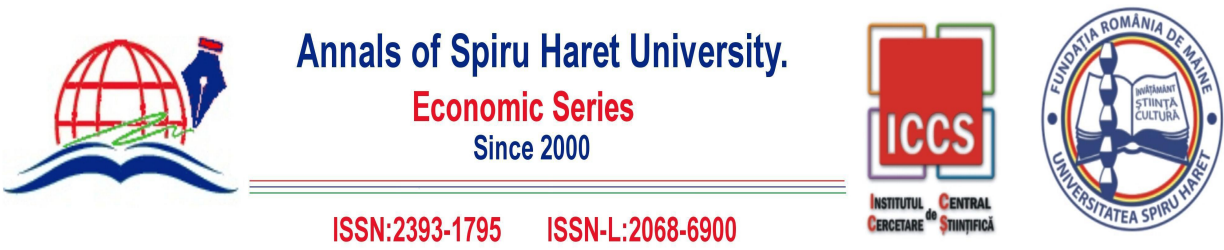

\section{Issue 2/2019}

And finally, despite of the fact that the gross domestic expenditures on R\&D in Lithuania remains low (see Fig. 8, Fig. 9), and the structure of those expenditures differs from other developed EU member states (higher education part dominates in the structure GD expenditures on $\mathrm{R} \& \mathrm{D}$, while the biggest part of investments for $R \& D$ comes from the business sector in other countries), Lithuania keeps the title of moderate innovators of innovation index.

However, results of European Innovation Scoreboard are changing every year: Lithuania got $24^{\text {th }}$ position in $2016,16^{\text {th }}$ position in 2017 and $20^{\text {th }}$ position in 2018. It shows efforts and the progress of the national innovation system (as the output).

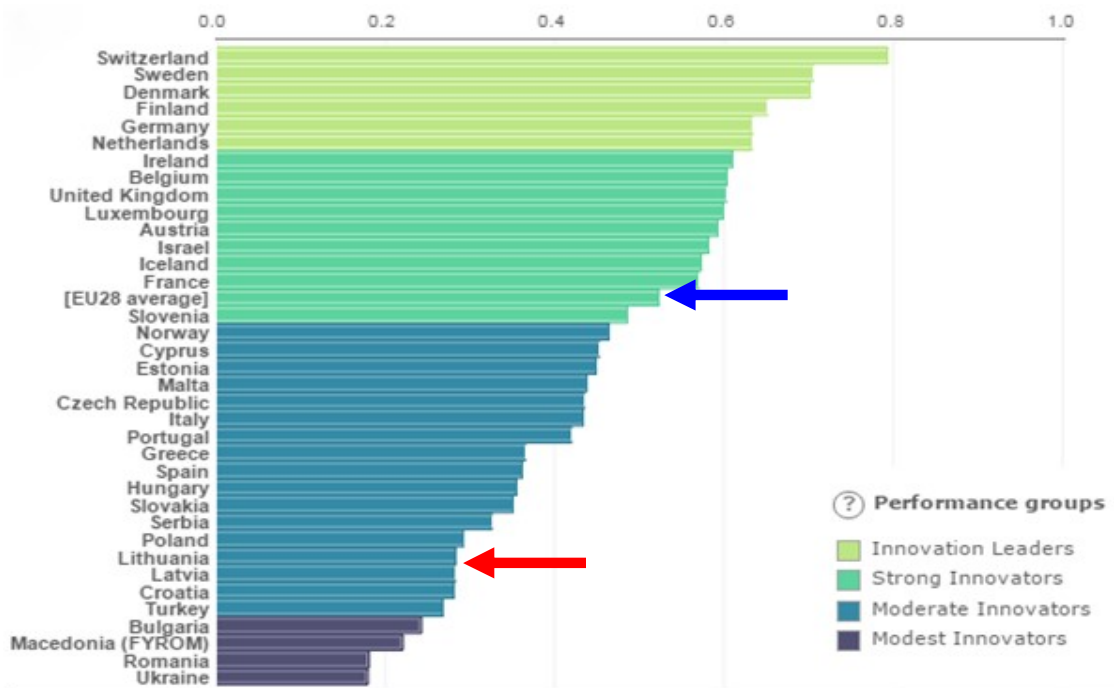

Fig. 9. Summary Innovation Index, 2016

Source: author's adapted from Levanti (2016)

In summarizing, Lithuanian NIS has some challenges due to human resources (the need of educated professionals) which can even grow in the next years, but at the same time the material input to innovative activities is quite good (especially the public part). Some problems of the private material contribution to the implementation of national 


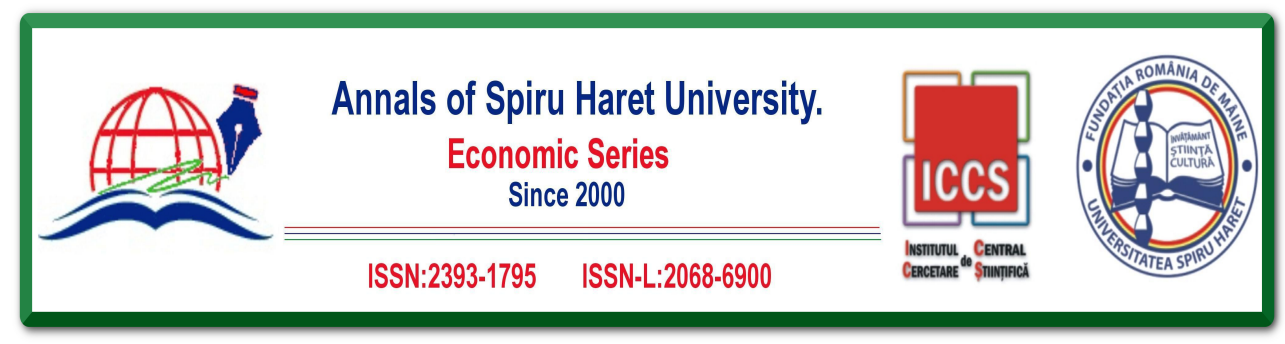

Issue 2/2019

innovation policy exist, so it needs some changes (changing mindset, interorganisational trust, the bigger support for public-private partnerships, etc.) to seek for better NIS results and position in the ratings of the Innovation index or scoreboards. This may require for the enabling of various innovation policy instruments, looking for some new ways of solutions. Besides, such changes must be leaded by excellent interinstitutional coordination and communication.

\section{Excellent communication and coordination}

Innovation policy is coordinated by two different national governmental institutions - Ministry of Economy and Ministry of Education and Science. Both of them must adjust their decisions and activity, must find channels and tools to ensure the constant and continuous coordination of the national innovation policy. It is not easy tasks due to the challenges for inter-institutional cooperation and communication. Sometimes decisions are not taken on time due to the long bureaucratic procedures to conform to laws, previous decisions, some institutional specifics, etc. The mission to ensure its excellence in the system of public administration (in the context of the dichotomy of policy and administration) is almost impossible.

Communication is one of the key issues ensuing good coordination. It is used not only for inter-institutional agreements, but for other vital activities of the national innovation policy (such as discussions and negotiations on political decisions, knowledge and technology transfer, informing, consulting, networking, etc.). However, communication in the NIS is considered as needed to be reviewed and developed [Makselis, 2014; Juknevičienè, 2015].

In summarizing the communication and the coordination of the implementation of Lithuanian innovation policy is identified as having some challenges and barriers to overcome.

\section{Conclusions and Discussion}

The theoretical analysis has revealed that the national innovation policy can be characterized by the complexity, orientation to the system and transformative change and the specifics of its instruments. Policy-makers must pay attention of those features while designing and planning policy implementation. Besides, if the policymaking process is mostly the task for the government, policy implementation is considered as the output of all NIS actors, therefore, the successful implementation can lead to the socio-economic growth (welfare) of the NIS. 


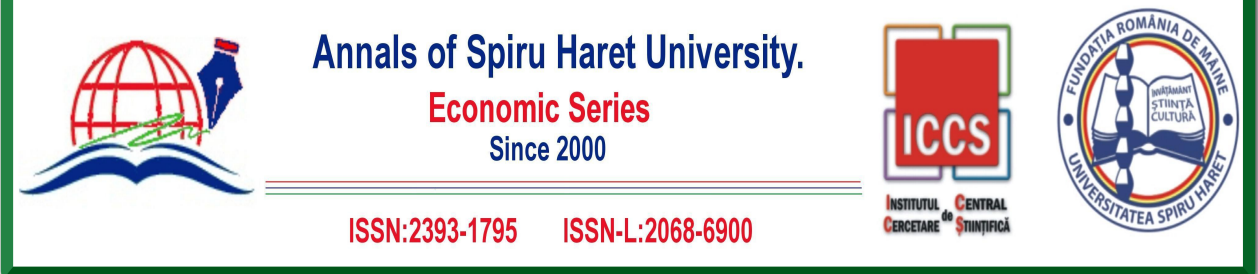

Issue 2/2019

The Rational model is convenient for the analysis of the successful implementation of the national innovation policy. This model can advice about possible outcomes and its elements can reveal strengths and weaknesses of the implementation process. This model can help to decide if needed features of the successful implementation success are satisfied.

Analysis of the situation of Lithuanian innovation policy and Lithuanian IS has revealed that the policy implementation still cannot be considered a successful one: clarity and logical consistence of objectives $(+/-)$, structured process $(+/-)$, committed implementers $(+)$, adequate resources $(+/-)$, excellent communication and coordination $(-/+)$.

Main barriers for the success have been identified as such: Lithuanian innovation policy is fragmented, oriented rather to short-term ecosystem measures than the longterm continuous development; the lack of highly competitive human resources in next period can cause the decrease of the progress; the lack of public and private $\mathrm{R} \& \mathrm{D}$ investments in long period can lead to the stagnation; the lack of trust, good coordination and communication between government, business and science interfere for the successful implementation.

However, stimulus for the successful implementation of the national innovation policy can be created taking into consideration identified strengths (such as clear strategic goals and committed actors in a NIS), named barriers and connected needs: the need for openness for professionals from abroad (immigration approach); the need for better coordination of EU funding and programs' management (education approach); the need for common projects and funded activities to develop the tradition of partnerships (society education and trust-building approach).

\section{References}

[1] Anderson, James E. Public policy making. An Introduction. Boston MA: Wadsworth, 2010.

[2] Bitrán, Ricardo (2017). "Tracking the Benefits Package from Paper to Practice. Monitoring and Evaluation." In What's In, What's Out - Designing Benefits for Universal Health Coverage, edited by Amanda Glassman, Ursula Giedion and Peter C. Smith, 61-87. Washington: Brookings Institution Press, Center for Global Development.

[3] Borrás, Susana and Edquist, Charles (2013). "The choice of innovation policy instruments." Technological Forecasting and Social Change 80(8): 1513-1522. 


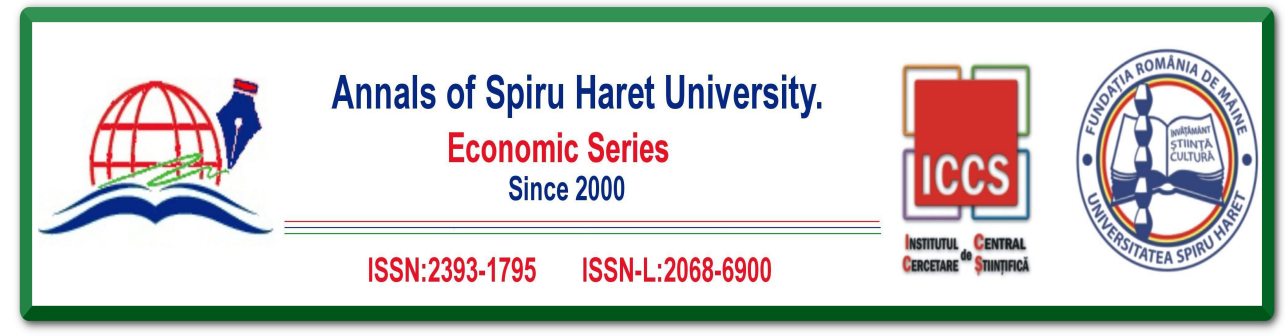

Issue 2/2019

[4] Bowen, Glenn A. (2009). "Document analysis as a qualitative research method." Qualitative research journal 9(2): 27-40.

[5] Brinkerhoff, Derick W. and Crosby, Benjamin L. Managing policy reform. Concepts and tools for decision-makers in developing and transitioning countries. Bloomfield, CT: Kumarian Press, 2002.

[6] Carayannis, Ellias G. and Provance, Mike (2008). "Measuring firm innovativeness: towards a composite innovation index built on firm innovative posture, propensity and performance attributes." International Journal of Innovation and Regional Development 1(1): 90-107.

[7] Community Innovation Survey (CIS). "The proportion of innovative enterprises fell below 50\% in the EU in 2010-2012", 2015. Accessed 21 May, 2019. https://ec.europa.eu/eurostat/documents/2995521/6483064/9-21012015-BP-EN.pdf/ ad7e4bf6-fc8f-459b-a47e-da1c9043bf2e.

[8] Corbin, Juliet and Strauss, Anselm Basics of qualitative research: Techniques and procedures for developing grounded theory (3rd ed.). Thousand Oaks, CA: Sage, 2008.

[9] Curral, Luis A., Forrester, Rosalind H., Dawson, Jeremy F. and West, Michael A. "It's what you do and the way that you do it: Team task, team size, and innovation-related group processes." European Journal of Work and Organizational Psychology 10(2) (2001): 187-204.

[10] den Hertog, Pim, Bergman, Edward, Charles, David. Innovative clusters: drivers of national innovation policy. OECD Publishing, 2001.

[11] Edler, Jakob and Fagerberg, Jan (2017). "Innovation policy: what, why, and how." Oxford Review of Economic Policy 1(33): 2-23.

[12] Edquist, Charles (2011). "Design of innovation policy through diagnostic analysis: identification of systemic problems (or failures)." Industrial and Corporate Change 20(6): 1725-1753.

[13] Edquist, Charles (2004). "Systems of Innovation: Perspectives and Challenges." In Oxford Handbook of Innovation, edited by Jan Fagerberg, David C. Mowery, 181-208. Oxford: Oxford University Press.

[14] Edquist, Charles (2001). "The Systems of Innovation Approach and Innovation Policy: An account of the state of the art". DRUID conference, Aalborg, 12-15.

[15] Etzkowitz, Henry and Leydesdorff, Loet (2000). "The dynamics of innovation: from national systems and "Mode 2" to a Tripple Helix of University-Industry-Government relations." Research Policy 29 (2): 109-123.

[16] Etzkowitz, Henry (2007). "University-Industry-Government: the Triple Helix Model of innovation." Proceedings of 51-st EOQ Congress, 22-23.

[17] European Commission. "Human resources in science and technology (HRST) by subgroups". Accessed 21 May, 2019. https://rio.jrc.ec.europa.eu/en/stats/human-resourcesscience-and-technology-hrst-sub-groups. 


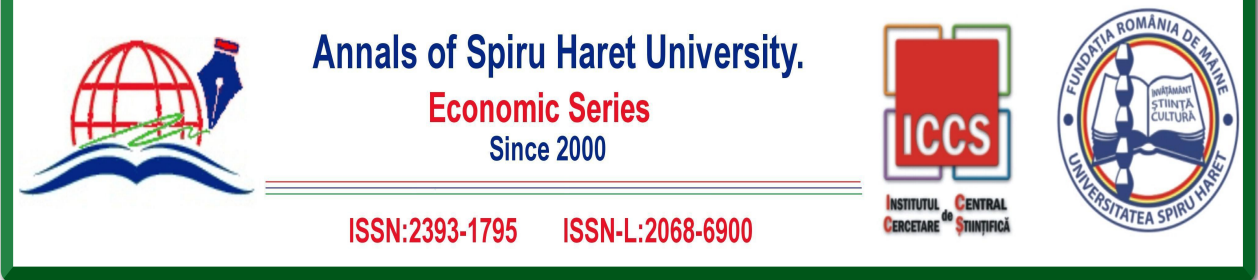

\section{Issue 2/2019}

[18] European Commission. "New doctoral graduates per thousand population aged 25-34". Accessed 21 May, 2019. https://rio.jrc.ec.europa.eu/en/stats/new-doctoral-graduatesthousand-population-aged-25-34.

[19] European Commission. "Private Enterprise Expenditure on R\&D (absolute value and intensity) - Lithuania” Accessed 21 May, 2019. https://rio.jrc.ec.europa.eu/en/countryanalysis/Lithuania/key-indicators/32692.

[20] European Commission. "Public (government and higher education) R\&D expenditure as \% of GDP - Lithuania". Accessed 21 May, 2019. https://rio.jrc.ec.europa.eu/en/ country-analysis/Lithuania/key-indicators/26108.

[21] Eurostat. "Gross domestic expenditure on R\&D, by sectors of performance, by country, 2016". Accessed 21 May, 2019. https://ec.europa.eu/eurostat/statisticsexplained/index.php?title=File: Gross_domestic_expenditure_on_R\%26D,_by_sectors_ of_performance,_by_country.png\&oldid $=288709 \#$ file.

[22] Florio, Massimo, Parteka, Aleksandra and Sirtori, Emanuela (2018). "The Mechanisms of Technological Innovation in SMEs: A Bayesian Network Analysis of EU Regional Policy Impact on Polish Firms". Technological and Economic Development of Economy 24(5): 2131-2160.

[23] Frenken, Koen (2017). "A complexity-theoretic perspective on innovation policy". Complexity, Innovation and Policy, 35-47.

[24] Hitt, Michael A., Ireland, R. Duane, Sirmon, David G. and Trahms, Cheryl A. (2011). "Strategic entrepreneurship: creating value for individuals, organizations, and society." Academy of management perspectives 25(2): 57-75.

[25] "Innovation policy". Ministry of the Economy and Innovations of the Republic of Lithuania, 2018. Accessed 20 January, 2019. http://eimin.lrv.lt/en/sector-activities/ innovation/innovation-policy.

[26] International Monetary Fund. "World Economic Outlook April 2015. Uneven Growth. Short- and Long-Term Factors", 2015. Accessed 10 January, 2019. http://www.imf.org/ external/ pubs/ft/weo/2015/01/pdf/text.pdf

[27] Johnston, Melissa P. (2014). "Secondary data analysis: A method of which the time has come." Qualitative and Quantitative Methods in Libraries 3(3): 619-626.

[28] Juknevičienè, Vita. "Regioninès inovacijų sistemos absorbcinio gebejimo vystymas (Development of regional innovation system's absorptive capacity)." Doctoral Dissertation, Kaunas University of Technology, 2015.

[29] Khan, Anisur Rahman and Khandaker, Shahriar (2016). "A Critical Insight into Policy Implementation and Implementation Performance." Viešoji politika ir administravimas $=$ Public Policy and Administration 4(15): 538-548.

[30] Lascoumes, Pierre and Le Galès, Patrick (2007). "Introduction: understanding public policy through its instruments - from the nature of instruments to the sociology of public policy instrumentation." Governance 20(1): 1-21. 


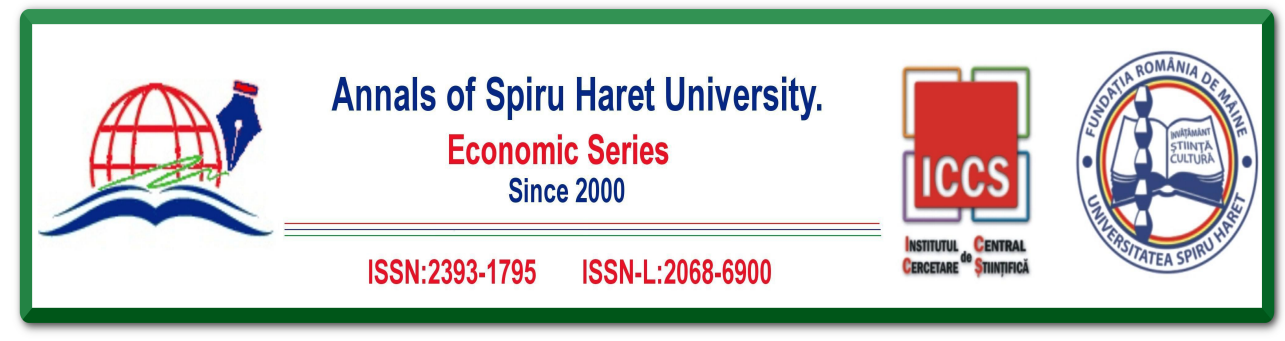

Issue 2/2019

[31] Levanti, Natasha. "Is UK innovation a competitive advantage?", 2016. Accessed 19 May, 2019. http://www.infrastructure-intelligence.com/article/jul-2016/uk-innovationcompetitive-advantage.

[32] Liotard, Isabelle and Revest, Valerie (2018). Contests as innovation policy instruments: Lessons from the US federal agencies' experience. Technological Forecasting and Social Change 127: 57-69.

[33] "Lithuania GDP - Gross Domestic Product. Lithuania records a drop in GDP in third quarter", 2018. Accessed 16 January, 2019. https://countryeconomy.com/gdp/lithuania

[34] "Lithuania's Progress Strategy «Lithuania 2030»", 2012. Accessed 16 January, 2019. https://rvv.lt/uploads/main/documents/files/EN_version/Useful_information/lithuania2030. pdf.

[35] "Lithuanian Innovation Development Programme 2014-2020", 2013. Accessed 10 January, 2019. https://mita.lrv.lt/en/ national-r-d-programmes/innovation-policy-inlithuania.

[36] Makselis, Rasius (2014). "Kūrybinès industrijos ir tarpsektorinė inovacijų sąveika (Creative Industries and Cross-Innovation)". Acta Academiae Artium Vilnensis 72: 7-30.

[37] Mazzucato, Mariana and Semieniuk, Gregor (2017). "Public financing of innovation: new questions." Oxford Review of Economic Policy 33(1): 24-48.

[38] Mazzucato, Mariana. The Entrepreneurial State: Debunking Private vs Public Sector Myths. London: Anthem Press, 2013.

[39] Meissner, Dirk, Polt, Wolfgang and Vonortas, Nicholas S. (2017). "Towards a broad understanding of innovation and its importance for innovation policy." The Journal of Technology Transfer 42(5): 1184-1211.

[40] Moon, Katie, Dickinson, Helen and Blackman, Deborah (2017). Not another review about Implementation? Reframing the research agenda. Public Service Research Group Issues Paper Series 1. Canberra: University of New South Wales.

[41] Mowery, David C. (2011) "Federal Policy and the Development of Semiconductors, Computer Hardware and Computer Software: A Policy Model for Climate Change R\&D?" In Accelerating Energy Innovation: Insights from Multiple Sectors, edited by Rebecca M. Henderson and Richard G. Newell, 159-188. Chicago: University of Chicago Press.

[42] Paliokaite, Agnè, Petraitè, Monika and Gonzalez Verdesoto, Elena. RIO Country Report 2017: Lithuania. Luxembourg: Publications Office of the European Union, 2018.

[43] Parsons, Wayne (2006). "Policy Analysis in Britain." In Handbook of public policy analysis, edited by Frank Fischer, Gerald J. Miller and Mara S. Sidney, 537-552. Boca Raton: CRC Press.

[44] Pülzl, Helga and Treib, Oliver (2006). "Implementing public policy.” In Handbook of public policy analysis, edited by Frank Fischer, Gerald J. Miller and Mara S. Sidney, 89108. Boca Raton: CRC Press. 


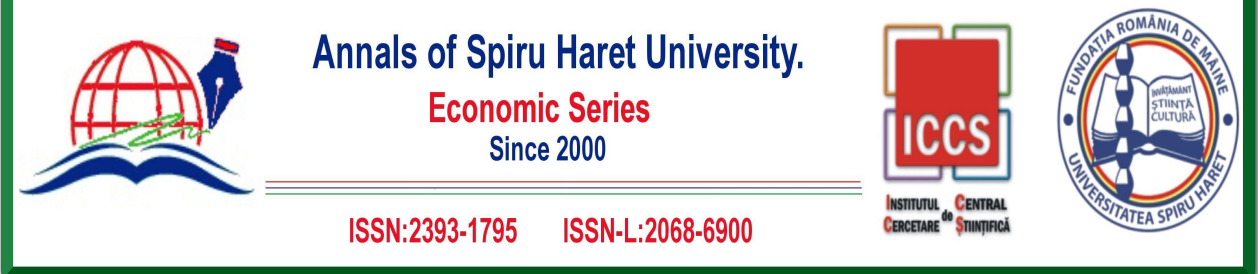

Issue 2/2019

[45] Ramstad, Elise (2009). "Expanding innovation system and policy-an organisational perspective." Policy studies 30(5): 533-553.

[46] Schot, Johan and Steinmueller, W. Edward (2018). "Three frames for innovation policy: R\&D, systems of innovation and transformative change." Research Policy 47(9): 1554-1567.

[47] Signé, Landry. Policy Implementation - A synthesis of the Study of Policy Implementation and the Causes of Policy Failure (No. 1703). OCP Policy Center, 2017.

[48] Singh, Rajiv. "Challenges of Implementing Policy in Public Organizations", 2017. Accessed 15 January, 2019. https://www.slideshare.net/RajivSingh66/challenges-ofpolicy-implementation-in-public-organizationsppt.

[49] Steward, Fred (2012). "Transformative innovation policy to meet the challenge of climate change: sociotechnical networks aligned with consumption and end-use as new transition arenas for a low-carbon society or green economy." Technology Analysis \& Strategic Management 24(4): 331-343.

[50] Stewart, John (1998). "Advance or retreat: from the traditions of public administration to the new public management and beyond." Public Policy and Administration 13(4): $12-27$.

[51] Tummers, Lars and Bekkers, Victor (2014). "Policy implementation, street-level bureaucracy, and the importance of discretion." Public Management Review 16(4): 527-547.

[52] Vedung, Evert (2017). "Policy instruments: typologies and theories." In Carrots, sticks and sermons. Policy Instruments and Their Evaluation, edited by Marie-Louise Bemelmans-Videc, Ray C. Rist and Evert Vedung, 21-58. London: Routledge.

[53] Weber, K. Matthias and Rohracher, Harald (2012). "Legitimizing research, technology and innovation policies for transformative change: Combining insights from innovation systems and multi-level perspective in a comprehensive 'failures' framework." Research Policy 41(6): 1037-1047.

[54] West, Michael A., Hirst, Giles, Richter, Andreas and Shipton, Helen (2004). "Twelve steps to heaven: Successfully managing change through developing innovative teams." European journal of work and organizational psychology 13(2): 269-299.

[55] Zhang, Xiaomeng and Bartol Kathryn M. (2010). "Linking empowering leadership and employee creativity: The influence of psychological empowerment, intrinsic motivation, and creative process engagement." Academy of management journal 53(1): 107-128. 